
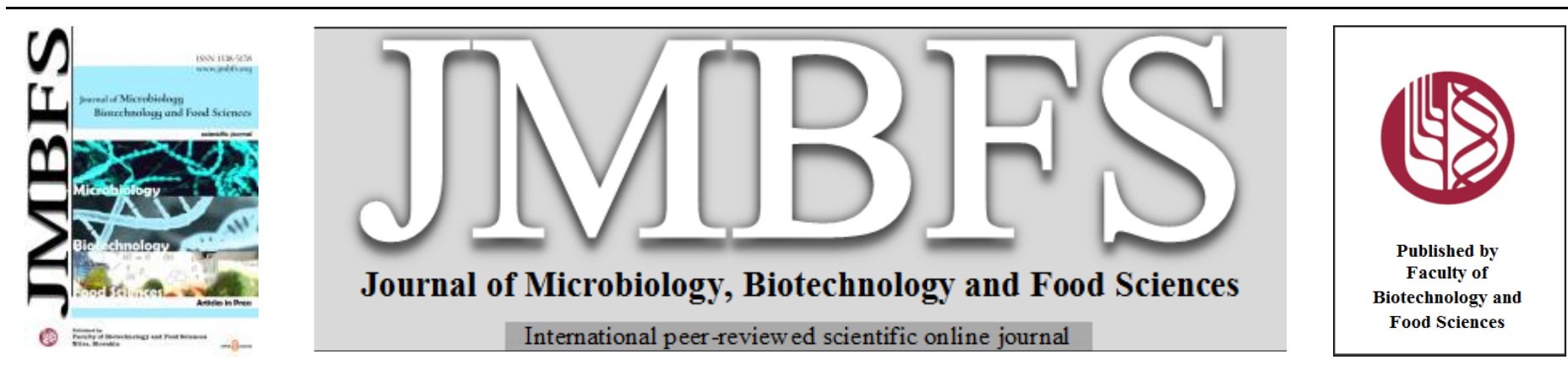

\title{
OPTIMIZATION OF MEDIA COMPONENTS AND PROCESS PARAMETERS FOR MICROBIAL MEDIATED REMEDIATION OF AZO DYES: A REVIEW
}

\author{
Rajeswari Uppala and Azhaguchamy Muthukumaran*
}

Address(es): Dr. Azhaguchamy Muthukumaran,

Department of Biotechnology, Kalasalingam Academy of Research and Education, Krishnankoil 626126, Tamil Nadu, India, Phone Number: $+91-9486276120$.

*Corresponding author: a.muthukumaran@klu.ac.in

https://doi.org/10.15414/jmbfs.3549

\section{ARTICLE INFO}

Received 6. 8. 2020

Revised 6. 8. 2021

Accepted 12. 8. 2021

Published 1. 12. 2021

\section{Review}

OPEN OACCESS

\begin{abstract}
Azo dyes are one of the most commonly used synthetic dyes with enormous applications in the textile industry. The recalcitrant properties of azo dyes could be attributed to the highly complex chemical organization. The limitations such as high cost and emergence of secondary toxic pollutants as by-products associated with physicochemical mode of degradation urged researchers to explore potential alternatives. Microorganisms having versatile metabolic pathways and adaptations to different environmental conditions gained the attention of researchers to exploit them for azo dyes degradation in a cost-effective manner. The azo dye degradation using microbial sources proved to be a promising approach as compared to conventional physicochemical approaches. Microorganisms can induce different metabolic pathways in response to the external environment. The biodegradation efficacy of the microorganisms-based approach can be maximized by optimizing the culture media and process parameters. Optimization techniques predict the conditions required to increase the efficacy of azo dyes degradation by microbial sources and also decrease the number of experimental runs to achieve the maximum percentage of degradation. Interaction of variables such as medium components and process parameters can be determined using optimization tools. Response Surface Methodology (RSM) and Artificial Neural Network (ANN) based optimization approaches were discussed in this review with special emphasis on microbial degradation of azo dyes.
\end{abstract}

Keywords: Optimization, Media Components, Process Parameters, Remediation, Azo Dyes

\section{INTRODUCTION}

The world has reached a stage where the increase in population enhances the demand for the enhanced manufacturing of value-added products, including foods, inks, cosmetics, paper and textiles. Synthetic dyes serve as the primary raw materials in manufacturing these valuable products of day-to-day use. According to an estimation, the number of commercially available synthetic dyes exceeds over 0.1 million with whopping production of different dyestuff (approximately $7 \times 10^{5}$ tons) annually, which corresponds to the massive and indiscriminate industrialization policies (Mohan et al., 2004). Among the synthetic dyes used in textile industries, the azo class of dyes, which are characterized by the presence of azo bonds $(-\mathrm{N}=\mathrm{N}-)$, constitute the most predominant synthetic dyes in the form of diversity. Azo dyes contribute a significant share in providing environmental contaminants in the form of toxic effluents and bypass the remediation treatments owing to their molecular complexity (Almeida \& Corso, 2014). The proportionate enhancement in the release of effluents in the form of wastewaters from textile industries owing to the indiscriminate application of synthetic dyes is the main cause of environmental pollution across the globe. Apart from the environmental effects, the extended stability of these synthetic dyes and by-products contributes to toxicity and mutagenicity in various life forms (A. B. dos Santos et al., 2007).

\section{Adverse effects of synthetic azo dyes}

The technological expansion and massive industrialization process provide valuable products of day to day use at ease; however, the effluent released from these industries, especially from the textile industries, contains different types of heavy metals as well as a variety of synthetic dyes. Among these dyes, due to high molecular weight and complex structures, azo dyes are considered as most important owing to its low biodegradability, high toxicity, capacity to produce ecological/ environmental disturbances and severe health consequences (Verma et al., 2012). Though the application of the azo dyes is widespread in food, pharmaceutical, textile, cosmetics and leather industries, its improper discharge to the environment followed by severe environmental consequences remains a critical issue to be taken care of (Chakraborty et al., 2013). Even in low concentration, azo dyes present in the industrial effluent has a drastic influence on the aquatic ecosystem and severe health consequences in human being owing to its carcinogenic property (Tan et al., 2016). In addition to that, the presence of the electron-deficient xenobiotic azo dyes in the industrial effluents has a characteristic influence on the development of mutagenesis, which ultimately affects the growth and development of human beings and other organisms (Saratale et al., 2011; R. L. Singh et al., 2015). For instance, the extensive use of azo dye, sunset yellow in food and packaging industries in the developed countries like the USA and Japan, leads to a detrimental effect on health owing to its severe cytotoxicity (Dwivedi \& Kumar, 2015). The products of dye-based industries mainly include the generation of effluents in the form of wastewater, which possesses serious problems such as groundwater depletion and environmental deterioration associated with ecosystem services. Besides, the exhaustive use of the highly reactive azo dyes in the textile industries resulting in development of severe health consequences such as allergic dermatitis and bladder cancer (Aravind $\boldsymbol{e t}$ al., 2016). Owing to the toxicity shown by azo dyes in the textile-based industries, they are considered as emerging and significant environmental contaminants with a significant impact on the health of aquatic organisms as well as humans (Ribeiro \& Umbuzeiro, 2014). The indiscriminate use of azo dyes in textile industries leads to the generation of effluents in the form of several intermediate and highly stable benzidine components, which have the inherent capacity of carcinogenicity with special reference to bladder cancer, prevalent in humans as well as animals (Chung, 2016). The xenobiotic and recalcitrant properties of azo dyes have a profound impact on human health, such as carcinogenic effects on the spleen and liver, chromosomal aberrations and nuclear anomalies (Puvaneswari et al., 2006). In addition to the textile industries, the food and pharmaceutical industries are the second most prevalent users of these synthetic azo dyes for packaged food and pharmaceutical products. The indiscriminate use of the highly stable artificial azo dyes in different foodbased industries leads to a severe loss of learning and memory function due to excessive brain tissue damage (Gao et al., 2011). The rigorous application of azo dyes as food additives and cosmetics leads to severe health hazards, including asthma and other associated health problems (Gil, 2014). 


\section{Chemical remediation of azo dyes and its limitations}

From the last few decades owing to the increase in urbanization and massive industrialization; an increase in the level of environmental pollutants and contaminants in the form of wastewater discharge from these industries has been observed. The indiscriminate use of the highly stable, recalcitrant azo dyes in these industries adversely affects not only the natural resources like soil fertility, aquatic biota but also affect the health of humans and ecosystem functioning. In this context, methods for proper reduction of these azo dyes from the wastewater effluents remain an uphill challenge (Sudha \& Saranya, 2014). Owing to the complex structural varieties found in the available azo dyes, they are readily resistant to aerobic biodegradation as well as convention wastewater treatmen technologies (Huang et al., 2015). Conventional wastewater treatment technologies such as adsorption, coagulation/ flocculation, membrane filtration, electrolysis and ozonization are employed for the removal of azo dyes associated with industrial effluents. These conventional techniques proved to be inadequate for complete removal of azo dyes owing to the constraints such as inefficacy, limited applicability, requires further secondary treatment, high cost, generation of highly toxic waste materials as well as potential secondary pollutants and lack of environmental friendliness (Asad et al., 2007; Pandey et al., 2007; Tahir et al., 2016). Besides, these conventional Physico-chemical based technologies are lagging behind to meet today's environmental conditions and demand for efficient dye removal and degradation from the industrial effluents (Du $\boldsymbol{e t}$ al. 2015). In addition to these constraints, these techniques also possess significant operational difficulties with the exploitation of more energy-intensive processes (Krishnan et al., 2017). Among the different physical/chemical/biological techniques used in the remediation of these azo dyes from the wastewater effluents, biological processes have received considerable attention owing to several advantages such as cost-effective operational procedures with comparatively less amount of sludge during the process and eco-friendly nature (Huang et al., 2015; Lalnunhlimi \& Krishnaswamy, 2016). Among the approaches involved for bioremediation of azo dyes from industrial sludge, exploitation of microorganisms in decolourization and degradation process vows to be a cost effective, high efficiency and ecofriendly alternative to the available conventional strategies (Deng et al., 2008; Li et al., 2015).

\section{Bacteria as a promising alternative to the remediation process}

Owing to the constraints shown by the conventional physical and physicochemical wastewater treatment technologies in the removal of azo dyes efficiently; the focus is shifting towards the exploitation of biological sources especially from microbial moieties due to their inherent and exceptional dye removal capacity. Microorganisms (bacteria, fungi, and yeast) have the inherent ability to synthesize a diverse group of enzymes with the potential to remove highly toxic azo dyes from the industrial effluents (Corso \& Maganha de Almeida, 2009). Among the microbial sources, the bioremediation strategies mainly center around the exploitation of bacterial biomass and products owing to the cost-effectivity, ecofriendly nature and comparatively less production of sludge during the remediation process as compared to physical/ chemical or other microbial sources. Bacterial bioremediation strategies mainly occur through the process of biosorption or degradation through the action of bacterial enzymes or could involve both the abovementioned approaches for effective neutralization of hazardous synthetic azo dyes (Solís et al., 2012). The efficacy of bacteria in azo dye decolorization/ degradation as compared to fungi can be attributed to its simplicity, cost-effectivity, a faster rate of decolorization and moreover inherent capacity to degrade the azo dyes reductively in an anaerobic condition (Ali, 2010; Khalid et al., 2008). In this context, the exploitation of bacteria in the remediation of azo dyes from industrial effluents proves to be the most economical alternative strategy evolved to date.

\section{Bioremediation of azo dyes by Gram + ve bacteria}

The bioremediation or decolourization of highly toxic azo dyes from textile effluents by exploitation of microorganisms, especially bacteria is extensively studied in the present scenario of obtaining better remediation efficacy with any harsh environmental effect. In this context, Bacillus sp. is the most studied organism in remediation of textile azo dyes effectively as compared to other bacterial species (Srinivasan $\boldsymbol{e t}$ al., 2014). An important constituent of textile wastewater is crystal violet, which is an important member of azo dyes family and hence its remediation is highly necessary in terms of minimizing environmental deterioration and health hazards. Shah et al. (2013) successfully investigated the efficacy of $B$. subtilis ETL-2211 in remediation of toxic crysta violet from the textile effluents which basically depends upon the optimized nutritional and environmental parameters (Shah et al., 2013). The efficacy of Bacillus sp. in remediation/ decolourization is not only limited to antharaquinone based dyes (Acid Blue) but also highly effective towards the decolourization of Malachite Green and Basic Blue X-GRRL (Deng et al., 2008). From severa decades, Indigo carmine is extensively exploited as an important dye in textile industries and strongly affect the health and also create environmental hazards. In this context, a cost effective and highly efficient remediation strategy should be applied to remediate highly toxic Indigo carmine from textile effluents. Li et al. (2015) successfully established the reductive decolourization of indigo carmine with the exploitation of Bacillus sp. MZS10 by virtue of its quinone dehydrogenase activity (Li et $\boldsymbol{a l}$., 2015). In 2013, Lysinibacillus sp. KMK-A was successfully investigated to mitigate the azo bond removal from azo dye Reactive Orange M2R from metal contaminated dye effluents in an eco-friendly manner (Chaudhari et al., 2013). Apart from Bacillus sp., Enterococcus faecalis YZ 66 is successfully exploited for its effective bioremediation of highly toxic azo dye, Reactive Orange 16 (Sahasrabudhe et al., 2014).

\section{Bioremediation of azo dyes by Gram -ve bacteria}

Degradation of synthetic azo dyes using chemicals will affect the ecological balance and also causes environmental problems and health hazards to human beings. Natural sources like microbes have a significant role in the removal of azo dyes from the environment. Degradation of Azo dyes using microorganisms is a most promising alternative to the conventional methods of bioremediation. Microorganisms show the key role in the degradation of synthetic azo dyes in an eco-friendly way. In this regard, the exploitation of Gram-negative bacteria and the enzymes produced by them in the remediation process is of prime importance. In this context, the enzyme i.e. laccase produced by Pseudomonas putida showed very promising bioremediation potential in remediating highly toxic synthetic azo dyes and other industrial effluents (Kuddus et al., 2013) Besides, Pseudomonas sp., Klebsiella sp., and Salmonella sp. also contributed substantially to remediate highly toxic synthetic textile azo dye, Orange 3R, from the industrial effluent under optimized conditions (Ponraj et al., 2011)

\section{Factors affecting the bioremediation of azo dyes}

Since the bacterial bioremediation process of many reactive dyes from the wastewater is comparatively faster and reliable than the fungal bioremediation process, considerable attention has been targeted towards the utilization of bacteria and bacterial-derived secondary metabolites for the bioremediation process. In addition, as complete mineralization and decolorization of reactive synthetic dyes depend upon the optimized conditions of cultural and nutritional parameters; formulating optimization parameters is highly important for the efficient remediation of the synthetic dyes as well as consistency in remediation (Kumar Garg et al., 2012; Lone et al., 2015). Carbon and nitrogen sources are used as nutritional parameters, whereas temperature, $\mathrm{pH}$, initial concentration of reactive dyes, incubation time, and agitation are used as process parameters for optimization (Khan et al., 2014).

\section{PROCESS OPTIMIZATION PARAMETERS AFFECTING BACTERIAI BIOREMEDIATION}

The optimization of the bacterial remediation process depends upon two types of optimization parameters, such as process/environmental parameters and the other one is the nutritional/medium optimization parameters. The initial concentration of reactive dyes, temperature, $\mathrm{pH}$, incubation time, agitation is regarded as the process optimization parameters.

\section{Temperature}

The incubation temperature critically determines the efficacy of bacterial bioremediation process as at different temperature range the growth and metabolites produced by concerned bacteria essentially differ which eventually affects the dye decolorization/ degradation process. Hassan et al. (2015) reported the optimized temperature for effective bioremediation of reactive red synozol, disperse yellow and disperse blue by Klebsiella spp. was $35^{\circ} \mathrm{C}$ (Hassan et al. 2015). Illakiam et al. (2016) also successfully investigated the optimized temperature range of $35-37^{\circ} \mathrm{C}$ for bioremediation of different synthetic dyes by the majority of bacteria. The results suggested the highest efficacy of Escherichia coli and Pseudomonas sp. in remediating Alizarin red $\mathrm{S}$ dye at the optimized temperature of $37^{\circ} \mathrm{C}$ (Illakkiam et al., 2016).

\section{pH}

The $\mathrm{pH}$ plays a pivotal role in maintaining the efficiency of dye decolorization, degradation and overall remediation process. Generally, the optimal $\mathrm{pH}$ for the majority of dye removal by bacteria is often ranged between 6.0 and 10.0 (Lavanya $\boldsymbol{e t}$ al., 2014). The textile industries utilize reactive azo dyes under alkaline conditions for high throughput productivity as these processes are directly dependent upon a different range of $\mathrm{pH}$. It was evident that at antimal $\mathrm{pH}$ range from 6-12, Clostridium bifermentans has the ability to completely decolorize Reactive Red 3B-A dye (Bardi \& Marzona, 2010). Singh et al. (2014) also reported earlier about the optimized pH of 7.0 for Staphylococcus hominis RMLRT03 for decolorization of Acid Orange (R. Singh et al., 2014) 


\section{The initial concentration of dyes}

The rate and amount of decolorization, degradation/mineralization of reactive synthetic dyes by bacteria is highly dependent upon the initial dye concentration as it directly affects the dye removal process owing to the availability on the adsorbent surface (Yagub et al., 2014). Ogugbue and Sawidis (2011) earlier reported the optimized initial concentration of Acid Red 249 to be $100 \mathrm{mg} / \mathrm{L}$ for effective remediation by Bacillus firmus (Ogugbue \& Sawidis, 2011). This result was further supported by the report given by Krishnan et al. (2017), where the results suggested that there was a marked decrease in the degradation efficacy when Brilliant Red X-3B, Direct Blue-6 and Direct Black-19 were used above $100 \mathrm{mg} / \mathrm{L}$ (Krishnan et al., 2017).

\section{Agitation}

The dye remediation capacity of bacteria mainly depends upon the agitation parameters as it directly/indirectly correlates with the oxygen requirement of bacteria. N. Arunagirinathan et al. (2017) recently reported the bioremediation efficacy of $E$. coli AKIP-2 in remediating Evan Blue dye under the optimized condition of agitation. The results suggested that the bacterial remediation of Evan Blue was maximized under static condition and the efficacy decreases with the increase in the agitation speed (N. Arunagirinathan et al., 2017). Simila results were obtained before, where three bacterial isolates, namely $P$ aeruginosa, $P$. putida and B. cereus attained maximized (90-94\%) dye remediation of an array of synthetic dyes such as Acid Red-151, Orange II, Sulfur Black and Drimarene Blue under static condition (Bayoumi et al., 2014).

\section{Incubation time}

The incubation period also plays a critical role in the bacterial bioremediation process. The highest efficacy of Bacillus sp. in remediating Acid Red 2 and Acid Orange 7 was observed with an optimized incubation period of 72 and $48 \mathrm{~h}$, respectively. The results suggested that under an optimized incubation period, the efficacy of remediation varies from organism to organism as well as for different dyes (Jaiswal \& Gomashe, 2017). The wide range of incubation periods was optimized for different bacteria targeting different reactive dyes, as reported earlier (Rajan et al., 2013).

\section{Medium optimization parameters affecting bacterial bioremediation}

\section{Carbon sources}

Along with the process parameters, nutritional/medium parameters optimization also plays a critical role in reactive dyes remediation by bacteria. Among the nutritional parameters, carbon sources are essential for the bacterial bioremediation process. Ebency et al. (2013) reported that Bacillus sp. efficiently remediate reactive dye, Indigo Blue, with an efficacy of $86.25 \%$ with sucrose as the sole carbon source (Ebency et al., 2013). Bheemaraddi et al. (2014) also reported that $P$. aeruginosa GSM3 effectively remediate the azo textile dye, Reactive violet 5 under different carbon sources, with glucose being the most efficient carbon source with $100 \%$ remediation within $24 \mathrm{~h}$ of incubation as compared to sucrose which attains maximum efficacy at 26h (Bheemaraddi et al., 2014).

\section{Nitrogen sources}

Nitrogen sources also interfere with the efficacy of decolorization and degradation of toxic azo dyes by bacteria. Gomaa, 2016 reported that four bacterial isolates such as B. subtilis, B. cereus, B. licheniformis and Pseudomonas sp. effectively remediate Black $B$ and Congo red when peptone and yeast extract were used as optimized nitrogen sources (Gomaa, 2016). Earlier investigations also suggested the efficacy of bacterial bioremediation of highly reactive RB5 dye using yeast extract as the sole nitrogen source (Johari, 2014).

\section{MICROBIAL ENZYME MEDIATED AZO DYES DEGRADATION}

Microbial degradation of dyes involves different intracellular and extracellular enzyme systems. The enzymatic mode of azo dyes degradation is brought about by azoreductase, laccases, hydroxylases and peroxidase. Laccases and azoreductase have the potential to decolorize synthetic dyes of different chemical class (R. L. Singh et al., 2015). Fungal enzymes also have the potential to oxidize a series of dyes due to their non-specificity towards dyes with varying structural conformations. The fungal enzymes such as peroxidase, laccase, manganese peroxidase and tyrosinase characteristically degrade textile dyes. On the other hand, bacterial biodegradation of dyes is generally associated with azo reductase, DCIP-reductase and laccase (H.S. Lade et al., 2012).

For example, B. laterosporus exhibited $100 \%$ decolorization of DR54 within $48 \mathrm{~h}$ of incubation under optimized conditions with an increase in the enzymatic activities of tyrosinase, veratrine alcohol oxidase and NADH--DCIP reductase (Kurade et al., 2016). Bacillus circulans BWL1061 decolorized methyl orange due to increased activity of azoreductase, NADH-DCIP reductase, and laccase (Liu et al., 2017). Salt-tolerant yeast Pichia occidentalis exhibited $98 \%$ decolorization of Acid Red B (ARB) with the involvement of NADH-DCIP reductase followed lignin peroxidase, manganese peroxidase and laccase (Song $\boldsymbol{e t}$ al., 2017).

Recently, consortial approaches have been gaining much interest in the remediation of textile dyes. In this system, the combined effects of various enzymes significantly enhances the dye degradation efficacy as compared to individual cultures. A consortium of Aspergillus ochraceus NCIM-1146 and Pseudomonas sp. SUK1 was reported for their ability to enhance dye decolorization of Rubine GFL to $95 \%$ in $30 \mathrm{~h}$ as compared to 46 and $63 \%$ decolorization when A. ochraceus NCIM-1146 and Pseudomonas sp. SUK1 was taken separately. The promising results could be attributed to the enhanced activity of laccase, veratryl alcohol oxidase, azo reductase and NADH-DCIP reductase. In another report, the bioremediation of Rubine GFL using a consortium of Galactomyces geotrichum MTCC 1360 and Brevibacillus laterosporus MTCC 2298 achieved 100\% decolorization due to the activation of laccase, veratryl alcohol oxidase, tyrosinase, azo reductase, and riboflavin reductase (Waghmode et al., 2012).

As presented in Table 1, microorganisms based reductive and oxidative enzymes are highly influential in the process of bioremediation. The complete degradation of azo dyes includes anaerobic decolorization in presence of flavin-dependent and flavin-independent azoreductases followed by an oxidative process in presence of peroxidases, laccases and tyrosinases (Mahmood et al., 2015). In a report of Lade et al. (2015) a bacterial consortium constituting of Providencia rettgeri HSL1 and Pseudomonas sp. SUK1 exhibited 98-99 \% decolorization of Reactive Black 5, Reactive Orange 16, Disperse Red 78 and Direct Red 81. The promising results could be attributed to the enhanced activity of azoreductase and NADH-DCIP reductase in the cleavage of complex azo interactions. Further, laccase and veratryl alcohol oxidase were reported for oxidation of toxic amines which are formed in the process (H. Lade et al., 2015).

\section{Azoreductases}

The bacterial membrane is inhabited by azoreductases known for cleaving the azo bonding using NADH or NADPH or $\mathrm{FADH}_{2}$ as an electron donor (Kurade $\boldsymbol{e}$ al., 2016). Under the action of azoreductases, the azo bridge cleaves, resulting in two arylamines that are usually toxic and carcinogenic in nature. Fortunately, laccase acts upon such amines and transforms them into their corresponding quinones and non-toxic by-products (Zucca $\boldsymbol{e t}$ al., 2016). These enzymes are oxygen sensitive and thus significantly inhibited by oxygen during the reduction mechanism (Sudha \& Saranya, 2014). Karatay et al. (2015) investigated removing azo dye, Remazol Blue using Bacillus megaterium, Micrococcus luteus and Bacillus pumilus. The study revealed an increase in azoreductase activity by $39.9 \mathrm{U} / \mathrm{mL}$ for $B$. pumilus (Karatay et al., 2015).

\section{Peroxidases}

Dye-decolorizing peroxidases are microbial hemoproteins that possess high substrate specificity and are known to successfully degrade azo dyes in the presence of hydrogen peroxide (A. Santos et al., 2014). Peroxidases are predominantly synthesized by fungal species during the process of dyes degradation. Fungal peroxidase isolated from Bjerkandera adusta efficiently decolorized azo dye present in industrial effluent (Baratto et al., 2015). Santos et al. (2014) identified two new bacterial dye-decolorizing peroxidases from $B$ subtilis and P. putida MET94. According to a report of Min et al. (2015), the peroxidase produced by $B$. subtilis KCTC2023 efficiently decolorize Reactive Blue19 and Reactive Black 5 (Min et al., 2015).

\section{Tyrosinases}

Tyrosinases are tetramer enzymes containing four copper atoms per molecule and binding sites for two aromatic compounds and oxygen. Similar to laccases, this class of phenol oxidases catalyzes the oxidation of aromatic compounds without the presence of cofactors. This enzyme could work on a number of substrates (Sudha \& Saranya, 2014). Franciscon et al. (2003) reported the influence of tyrosinase in the remediation of Reactive Yellow 107, Reactive Black 5, Reactive Red 198 and Direct Blue 71 by Brevibacterium sp. VN-15 (Franciscon et al., 2012).

\section{Laccases}

Laccase is a low molecular weight, copper-containing polyphenol oxidases found in plants, insects, bacteria and fungi (Yan et al., 2014). Laccases have the inherent potential to oxidize a wide variety of aromatic compounds due to nonspecific oxidation capacity, non-requirement of cofactors and ability to use readily available oxygen using $\mathrm{Cu}^{2+}$ as the mediator. They have been studied extensively for their oxidizing effect towards various dyes (Phugare $\boldsymbol{e t}$ al., 2011). Laccases oxidize the azo dye to generate a phenoxy radical which is subsequently re-oxidized to produce carbonium ion by cross-coupling of the 
reactive species, including the formation of $\mathrm{C}-\mathrm{C}$ and $\mathrm{C}-\mathrm{O}$ bonds between phenolic molecules and formation of $\mathrm{C}-\mathrm{N}$ and $\mathrm{N}-\mathrm{N}$ bonds between aromatic amines (R. L. Singh et al., 2015). White-rot fungi particularly Trametes sp. are the predominant source for laccases with characteristic features such as resistance to high alkalinity, extreme acidity, organic solvents, heavy metals and high thermal stability. Hence, Trametes sp. derived laccases have gained considerable attention (Yan et al., 2014). Several laccase-producing fungal cultures were reported for the degradation of azo dyes (Table 1). However, high temperature and alkaline conditions are the limitations associated with fungal-derived laccase (R. L. Singh et al., 2015; Sudha \& Saranya, 2014)

Depending on the species and environmental conditions, fungal laccases are often secreted extracellularly in the form of different isoenzymes (R. L. Singh et al., 2015). According to He et al. (2014), three laccase isoenzymes were purified from Ganoderma sp. En3. The isoenzymes exhibited promising decolorization ability. However, the enzymatic decolorization of dyes was efficiently enhanced when different laccase isoenzymes were used in combination due to their synergistic effect (He et al., 2015).
The laccase activity is also influenced by the media composition and the conditions of fermentation. Metal ions such as copper and manganese also regulate the expression of regulatory genes encoding laccase isoenzymes (He $\boldsymbol{e}$ al., 2015). Jiang et al. (2013) reported the activation of laccase isoenzyme produced by Coprinus comatus and its dye decolorization efficacy. The production of laccase isoenzyme and the enzymatic activity were influenced by the $\mathrm{C} / \mathrm{N}$ ratio, aromatic compounds and copper content. At the optimal conditions of high-nitrogen and low-carbon, C. comatus produced six laccase isoenzymes with an efficiency of more than $90 \%$ when crude laccase was used to remediate Reactive Brilliant Blue K-3R, Reactive Dark Blue KR, and Malachite Green (Jiang et al., 2013). Zhuo et al. (2017) reported the synergistic effect of $\mathrm{Fe}^{2+}$ and $\mathrm{Cu}^{2+}$ ions and aromatic compounds (vanillic acid, cinnamic acid, and ferulic acid) on the increased production of extracellular laccase in P. ostreatus HAUCC 162 In addition, the crude laccase significantly decolorized Methyl orange (Zhuo et al., 2017)

Table 1 Microbial enzyme mediated degradation of azo dyes.

\begin{tabular}{|c|c|c|c|}
\hline Enzymes & Organism & Dye & Reference \\
\hline Manganese peroxidase & Phanerochaete sordid YK-624 & Reactive Red 120 & (Harazono et al., 2003) \\
\hline Peroxidase, Laccase, and Azoreductase & Exiguobacterium sp. RD3 & Reactive blue 172 & (Dhanve et al., 2008) \\
\hline Laccase & Pseudomonas sp. SU-EBT & Congo red & (Telke et al., 2010) \\
\hline $\begin{array}{l}\text { Laccase, Veratryl alcohol oxidase, Azo } \\
\text { reductase and NADH-DCIP reductase }\end{array}$ & $\begin{array}{c}\text { A. ochraceus NCIM-1146 } \\
\text { and Pseudomonas sp. SUK1 }\end{array}$ & Rubine GFL & (H. S. Lade et al., 2012) \\
\hline $\begin{array}{l}\text { Tyrosinase, Veratryl alcohol oxidase and } \\
\text { NADH--DCIP reductase }\end{array}$ & Brevibacillus laterosporus & Disperse Red 54 & (Kurade et al., 2016) \\
\hline $\begin{array}{l}\text { NADH-DCIP reductase, Peroxidase, } \\
\text { Manganese peroxidase and Laccase }\end{array}$ & Pichia occidentalis & Acid Red B & (Song et al., 2017) \\
\hline Laccase and Reductase & Pseudomonas species & Reactive Orange 16 & $\begin{array}{l}\text { (J. P. Jadhav et al., } \\
\text { 2010) }\end{array}$ \\
\hline
\end{tabular}

\begin{tabular}{l} 
Azo reductase, NADH-DCIP reductase, \\
Veratryl alcohol oxidase and Tyrosinas \\
\hline
\end{tabular}

Azoreductase,

Brevibacillus laterosporus

\begin{tabular}{lc}
\hline Alcohol oxidase & P. aeruginosa $\mathrm{BCH}$
\end{tabular}
Lignin peroxidase and Laccase

Sphingomonas paucimobilis, $B$

cereus ATCC14579, $B$.

cereus ATCC 11778

Alcohol oxidase

Comamonas UVS
Providencia rettgeri HSL1 and Pseudomonas sp. SUK1
Remazol red and Rubine GFL

Methyl orange Remazol Black

Red HE7B and Direct Blue GLL

Reactive Black 5 (RB 5), Reactive Orange 16

(RO 16), Disperse Red 78 (DR 78) and Direct Red 81 (DR 81)

Red 81 (DR 81)

G. geotrichum MTCC 1360 and B laterosporus MTCC 2298

Rubine GFL

(Kurade et al., 2013)

(Ayed et al., 2010)

(Phugare et al., 2011)

(U. U. Jadhav et al. 2009)

(H. Lade et al., 2015)

Laccase, Veratryl alcohol oxidase,

Tyrosinase, Azo reductase, And

Riboflavin reductase

\begin{tabular}{lc}
\hline Laccase & Trametes trogii $\mathrm{S} 0301$ \\
\hline $\begin{array}{l}\text { Response surface methodology (RSM) for Optimization of azo dyes } \\
\text { remediation }\end{array}$
\end{tabular}

\section{Laccase}

The dye remediation process is governed under the influence of numerous factors and their combined effect of which directly determines the process efficiency and performance of the designed system. Hence, for prediction and optimization of the process variables, different experimental models were designed and developed statistically (Witek-Krowiak et $\boldsymbol{a l}$., 2014). The optimization process aims to identify the specific set of parameters that will result in the best possible outcome. Usually, for determining the effect of process variables, the One Variable at Time (OVAT) method is used where the independent variable is systemically changed while keeping the other parameters constant. However, this method is costly and time-consuming as all process variables are screened independently. Further, OVAT cannot provide any details on the interactions between the selected variables (Kaur et al., 2015).

Hence, in the quest for experimental models to optimize the different variables in a multivariable system, RSM and Artificial Neural Network (ANN) are gaining much popularity as powerful data modeling tool ${ }^{82}$. The statistical design of experiments (DOEs) associated with RSM experimental models has the inherent potential to define complex non-linear interactions between different independent variables and the resulting responses (Kaur et al., 2015). In recent times, process parameters including initial dye concentration, $\mathrm{pH}$, temperature and inoculum size are optimized using the RSM tool for efficient decolorization/degradation of synthetic dyes. One of the advantages of employing RSM is the determination of the effect of independent variables on the interactions of process parameters with a minimum number of experimental runs (Senthilkumar et al., 2012). Hence, RSM improves process performance, reduces operation costs and experimental time (Witek-Krowiak et al., 2014). Maqbool et al. (2016) reported the optimum salt content, $\mathrm{pH}$, carbon content, concentration of metal mixtures using the RSM

tool for determining the efficacy of $P$. aeruginosa ZM130 in decolorizing reactive red-120 (Maqbool et al., 2016).

Several RSM designs have been developed and employed to optimize the biosorption process. As presented in Table 2, central composite design (CCD), Box-Behnken design (BB) and Plackett-Burman (PB) design have been widely employed to optimize numerous parameters associated with the decolorization of dyes. Design Expert (Stat-Ease, Inc.), Minitab (Minitab Inc.), Statistica (StatSoft), JMP (SAS) and Matlab (MathWorks) are widely used to study RSM based optimization of parameters in remediation of synthetic dyes. The response obtained in the form of 3D-graph and/or contour plot serve as a fast way of modelling when the optimal response is within experimental boundaries (WitekKrowiak et al., 2014)

\section{Central composite design $(\mathrm{CCD})$}

For high-quality predictions on linear and quadratic interaction effects of variables, $\mathrm{CCD}$ is widely used as a promising statistical design. The CCD constitutes fractional factorial design at two levels $\left(2^{n}\right)$, center points $(\mathrm{cp})$, which corresponds to the middle level of the factors, and axial points $(2 n)$ (WitekKrowiak et al., 2014). Dietzia sp. PD1 biodegraded Congo red and indigo and two levels three-factor $\left(2^{3}\right) \mathrm{CCD}$ was employed for optimization of $\mathrm{pH}$, initial dye concentration and incubation time. At the optimized levels, the biodegradation efficacy for Congo red and indigo carmine was observed to be 99.97 and 99.95\%, respectively (P. Das et al., 2016). Hafshejani et al. (2013) reported the decolorization and degradation of Direct Blue 71 by $P$. aeruginosa with the three-level CCD to optimize different variables. At the optimal conditions of $35^{\circ} \mathrm{C}, \mathrm{pH} 8.0$ and $49.9 \mathrm{mg} / \mathrm{L}$ initial dye concentration, the decolorization efficacy was observed to be $84.80 \%$ (Hafshejani et al., 2014). In a report by Senthilkumar et al. (2012), three-level CCD was employed to 
optimize initial dye concentrations, carbon source and nitrogen source for efficient decolorization of Remazol Turquoise Blue (RTB) and Reactive Black 5 (RB5) using Pseudomonas sp. (Senthilkumar et al., 2012). In a similar experiment, the effect $\mathrm{pH}$, incubation time, and concentration of dye on decolorization efficacy of Cordyceps militaris were determined using CCD model (Kaur et al., 2015). Yan et al. (2014) reported enhanced laccase production in $T$. trogii S0301 using CCD of RSM. On process optimization, the maximum laccase activity was attained at an optimum $\mathrm{pH}$ of 3.0 and temperature of $45^{\circ} \mathrm{C}$. Further, the purified laccase was found to significantly decolorized malachite green, bromophenol blue, crystal violet and acid red (Yan et al., 2014).

\section{Box-Behnken design (BB)}

Box and Behnken design (BB) is a 3-level incomplete factorial design developed to minimize the number of experiments and extensively used in the optimization of numerous factors involved in dye removal. In BB design, The experiment matrices are constructed by means of two-level factorial designs $(+1,-1)$ with incomplete block designs (Witek-Krowiak et al., 2014). Garg et al. (2015) reported bioremediation of Reactive Orange 4 using Pseudomonas putida SKG-1. As indicated by the RSM-based BB design, the $97.8 \%$ decolorization was achieved at an optimized dye concentration of $50 \mathrm{mg} / \mathrm{L}$, sucrose $0.7 \%$, and peptone $0.28 \%$ upon $72 \mathrm{~h}$ of incubation (Garg \& Tripathi, 2017). RSM-based BB design was employed by Das \& Mishra (2017) in order to optimize the process parameters for efficient removal of Reactive Green-19 using bacterial consortium. The dye removal efficacy was observed to be $97 \%$ at the optimized temperature of $32{ }^{\circ} \mathrm{C}, \mathrm{pH} 8.3$ and Yeast Extract concentration of $1.16 \mathrm{~g} / 100 \mathrm{~mL}$ (A. Das \& Mishra, 2017). Sathian et al. (2013) also utilized BB design in order to optimize the levels of $\mathrm{pH}$, temperature, agitation speed and dye concentration for determining the efficacy of Pleurotus floridanus in treatment of textile dye wastewater (Sathian et al., 2013). The decolorization of Solophenyl red 3BL (SR) by Fomes fomentarius laccase was studied using RSM-based BB. The results indicated the optimal conditions with enzyme concentration of $0.8 \mathrm{U} / \mathrm{mL}$ mediator concentration of $33 \mu \mathrm{M}$, and time of $14 \mathrm{~h} 30 \mathrm{~min}$. The predicted optimal conditions resulted in $79.66 \%$ of decolorization, which significantly correlates with the predicted value of $80.70 \%$ (Neifar et al., 2011)

\section{Plackett-Burman design (PB)}

The PB design was developed to determine the main factor effects for a process consisting of multiple variables in a short experimental time. In PB design, the number of experiments is equal to the number of parameters in the first order RSM model $(N=k+1)$, and the degree of freedom is equal to zero (WitekKrowiak et al., 2014). Hema and Suresha (2015) evaluated the ability of Penicillium oxalicum RF3 in decolorizing Isolan grey by employing RSM based PB design. At the predicted optimal parameters, an enhanced decolorization of Isolan grey was attained with maximum decolorization of $50.75 \%$ (Hema $\&$ Suresha, 2015).

Table 2 Optimization of bacterial remediation of azo dyes using Response surface methodology (RSM)

\begin{tabular}{|c|c|c|c|c|}
\hline Organism & Dye & Parameters & RSM design & Reference \\
\hline Pseudomonas sp. & Congo red, Reactive red 195 & $\begin{array}{l}\text { initial dye concentration, carbon source, } \\
\text { nitrogen source }\end{array}$ & $\begin{array}{l}\text { central composite } \\
\text { design }(\mathrm{CCD})\end{array}$ & $\begin{array}{c}\text { (Senthilkumar } e t \\
\text { al., 2013) }\end{array}$ \\
\hline $\begin{array}{l}\text { Pseudomonas } \\
\text { aeruginosa }\end{array}$ & Direct Blue 71 & $\begin{array}{c}\text { temperature, medium } \mathrm{pH} \text {, initial dye } \\
\text { concentration }\end{array}$ & $\begin{array}{c}\text { central composite } \\
\text { design (CCD) }\end{array}$ & $\begin{array}{c}\text { (Hafshejani et al., } \\
\text { 2014) }\end{array}$ \\
\hline Pseudomonas sp. & Remazol Turquoise Blue, Reactive Black 5 & $\begin{array}{c}\text { concentrations of Dye, Carbon source, } \\
\text { Nitrogen source }\end{array}$ & $\begin{array}{l}\text { central composite } \\
\text { design }(\mathrm{CCD})\end{array}$ & $\begin{array}{c}\text { (Senthilkumar } e t \\
\text { al., 2012) }\end{array}$ \\
\hline Dietzia sp. PD1 & $\begin{array}{c}\text { Congo red, } \\
\text { Indigo carmine }\end{array}$ & $\mathrm{pH}$, initial dye concentration, time & $\begin{array}{c}\text { central composite } \\
\text { design }(\mathrm{CCD})\end{array}$ & (P. Das et al., 2016) \\
\hline $\begin{array}{l}\text { Pseudomonas } \\
\text { aeroginosa PAO1 } \\
\text { Stenotrophomonas } \\
\text { maltophila, } \\
\text { Proteus mirabilis } \\
\end{array}$ & Direct Black 22 & $\begin{array}{l}\text { Glucose concentration, yeast extract } \\
\text { concentration, dye concentration, } \\
\text { inoculum size }\end{array}$ & $\begin{array}{l}\text { central composite } \\
\text { design }(\mathrm{CCD})\end{array}$ & $\begin{array}{l}\text { (Mohana et al., } \\
\text { 2008) }\end{array}$ \\
\hline $\begin{array}{l}\text { Cordyceps } \\
\text { militaris MTCC3936 }\end{array}$ & $\begin{array}{c}\text { Reactive yellow } 18, \text { Reactive red } 31 \text {, } \\
\text { Reactive black } 8 \text {, Reactive green } 19 \\
\text { Reactive red } 74 .\end{array}$ & $\begin{array}{c}\mathrm{pH} \text {, incubation time, the concentration of } \\
\text { dye }\end{array}$ & $\begin{array}{l}\text { Centre composite } \\
\text { rotatable design } \\
(\mathrm{CCRD}) \\
\end{array}$ & (Kaur et al., 2015) \\
\hline Trametes trogii laccase & $\begin{array}{l}\text { Malachite green, Bromophenol blue, } \\
\text { Crystal violet, Acid red }\end{array}$ & $\mathrm{pH}$, temperature & $\begin{array}{l}\text { central composite } \\
\text { design }(\mathrm{CCD})\end{array}$ & (Yan et al., 2014) \\
\hline $\begin{array}{l}\text { Pseudomonas } \\
\text { aeruginosa } \mathrm{BCH}\end{array}$ & Remazol Orange & $\mathrm{pH}$, temperature, cell mass concentration & Box-Behnken design & $\begin{array}{l}\text { (S. B. Jadhav et } \\
\text { al., 2013) }\end{array}$ \\
\hline $\begin{array}{l}\text { Pseudomonas } \\
\text { putida SKG-1 }\end{array}$ & Reactive orange 4 & $\begin{array}{l}\text { Dye concentration, sucrose, peptone, } \\
\text { incubation time }\end{array}$ & Box-Behnken design & $\begin{array}{c}\text { (Garg \& Tripathi, } \\
\text { 2017) } \\
\end{array}$ \\
\hline Bacillus subtilis & Disperse Yellow 211 & $\begin{array}{l}\text { temperature, } \mathrm{pH} \text { and initial dye } \\
\text { concentration }\end{array}$ & Box-Behnken design & $\begin{array}{c}\text { (Sharma et al., } \\
\text { 2009) }\end{array}$ \\
\hline Bacterial consortium & Reactive Green-19 & $\begin{array}{l}\mathrm{pH} \text {, incubation temperature, Yeast extract } \\
\text { concentration }\end{array}$ & Box-Behnken design & $\begin{array}{c}\text { (A. Das \& Mishra, } \\
\text { 2017) }\end{array}$ \\
\hline $\begin{array}{l}\text { Fomes } \\
\text { fomentarius laccase }\end{array}$ & Solophenyl red 3BL & $\begin{array}{l}\text { enzyme concentration, redox mediator } \\
\text { concentration, incubation time }\end{array}$ & Box-Behnken design & (Neifar et al., 2011) \\
\hline $\begin{array}{l}\text { Penicillium oxalicum } \\
\text { RF3 }\end{array}$ & Isolan Grey & $\begin{array}{l}\text { Inoculum size, media components, } \mathrm{pH}, \\
\text { temperature, dye concentration, } \\
\text { incubation time }\end{array}$ & Plackett-Burman & $\begin{array}{l}\text { (Hema \& Suresha, } \\
\text { 2015) }\end{array}$ \\
\hline
\end{tabular}

Optimization of bacterial remediation of azo dyes using artificial neural network (ANN)

Apart from RSM, ANN proved to be a valuable tool in modeling and optimization of variable parameters for efficient removal of dyes. The efficacy of ANN could be attributed to recognize and reproduce cause-effect relationships through evaluation for multiple input-output systems. The statistical aspect of ANN aids in determining the factors which have a significant effect on the biosorption process. Using ANN, the number of experiments needed in an experimental design and time can be significantly reduced (Witek-Krowiak $\boldsymbol{e}$ al., 2014). ANN is useful in simulating and up-scaling complex biological processes even without the description of the phenomena involved in the process (Ghaedi et al., 2014).

In a report of Khataee et al. (2010) the three-layered feed-forward back propagation ANN model was employed to predict the decolorization efficiency of Chara sp. towards Malachite Green (MG). The process parameters like temperature, $\mathrm{pH}$, initial dye concentration, reaction time and amount of algae on the decolorization efficiency were studied. The findings indicated that ANN provides reasonable predictive performance $(\mathrm{R} 2=0.970)($ Khataee $\boldsymbol{e t}$ al., 2010) Yang et al. (2011) documented the ANN-based modeling for the biosorption of Acid Black 172 (AB) and Congo red (CR) using Penicillium YW 01. Initial dye concentration and temperature were observed to be the most influential parameters for biosorption process as per the ANN-based analysis (Yang $\boldsymbol{e t}$ al. 2011). Das et al. (2015) documented the correlation between the input process variables and output parameters for degradation of Congo red and indigo carmine using Dietzia sp. PD1 by utilizing the ANN model (P. Das et al., 2016).

\section{CONCLUSION}

An overview of various methods being employed to design and optimize dye degradation/decolorization was described. The microbial degradation efficacy depends upon the optimized levels of nutrients, $\mathrm{pH}$, temperature, oxygen. These nutritional parameters can be optimized to enhance bioremediation efficacy using numerous software-based algorithms. Microbial enzymes based decolorization potential was also thoroughly described. Enzymes such as azoreductase, laccases, peroxidase, and hydroxylases are highly important in enhancing the degradation 
of azo dyes. Recently, the consortial approaches have been gaining much interest in the remediation of textile dyes as the combined effects of various enzymes enhance dye degradation compared to individual cultures. The exploitation of microbial biosorbents as an efficient remediation approach instead of conventional approaches was also described in detail. Further, the involvement of RSM and ANN-based statistical tools promising alternative to predict and optimize the different variables in order to increase the efficacy of bioremediation of dyes. Hence, microorganism-mediated remediation of azo dyes serves as an efficient, cost-effective and eco-friendly alternative to the conventional Physico-chemical process for efficient removal and degradation of azo dyes from the industrial effluents.

Acknowledgments: We would like to express our heartfelt thanks to Kalasalingam University, Krishnankoil-626126, Tamil Nadu, India, for the support.

\section{Conflict of Interest: The authors declare that there is no conflict of interest.}

Authors' Contributions: All authors listed have made a substantial, direct and intellectual contribution to the work and approved it for publication.

\section{Funding: None.}

Data Availability: All datasets generated or analyzed during this study are included in the manuscript and the Supplementary Files.

\section{Ethics Statement: Not applicable.}

\section{REFERENCES}

Ali, H. (2010). Biodegradation of Synthetic Dyes-A Review. Water, Air, \& Soil Pollution, 213(1-4), 251-273. https://doi.org/10.1007/s11270-010-0382-4

Almeida, E. J. R., \& Corso, C. R. (2014). Comparative study of toxicity of azo dye Procion Red MX-5B following biosorption and biodegradation treatments with the fungi Aspergillus niger and Aspergillus terreus. Chemosphere, 112 317-322. https://doi.org/10.1016/j.chemosphere.2014.04.060

Aravind, P., Selvaraj, H., Ferro, S., \& Sundaram, M. (2016). An integrated (electro- and bio-oxidation) approach for remediation of industrial wastewater containing azo-dyes: Understanding the degradation mechanism and toxicity assessment. Journal of Hazardous Materials, 318, 203-215. https://doi.org/10.1016/j.jhazmat.2016.07.028

Asad, S., Amoozegar, M. A., Pourbabaee, A. A., Sarbolouki, M. N., \& Dastgheib, S. M. M. (2007). Decolorization of textile azo dyes by newly isolated halophilic and halotolerant bacteria. Bioresource Technology, 98(11), 2082 2088. https://doi.org/10.1016/j.biortech.2006.08.020

Ayed, L., Khelifi, E., Jannet, H. Ben, Miladi, H., Cheref, A., Achour, S., \& Bakhrouf, A. (2010). Response surface methodology for decolorization of azo dye Methyl Orange by bacterial consortium: Produced enzymes and metabolites characterization. Chemical Engineering Journal, 165(1), 200-208 https://doi.org/10.1016/i.cej.2010.09.018

Baratto, M. C., Juarez-Moreno, K., Pogni, R., Basosi, R., \& Vazquez-Duhalt, R. (2015). EPR and LC-MS studies on the mechanism of industrial dye decolorization by versatile peroxidase from Bjerkandera adusta. Environmental Science and Pollution Research, 22(11), 8683-8692. https://doi.org/10.1007/s11356-014-4051-9

Bardi, L., \& Marzona, M. (2010). Factors Affecting the Complete Mineralization of Azo Dyes. In Handbook of Environmental Chemistry (Vol. 5, Issue Part N, pp. 195-210). https://doi.org/10.1007/698_2009_50

Bayoumi, M. N., Al-wasify, R. S., \& Hamed, S. R. (2014). Bioremediation of Textile Wastewater Dyes using Local Bacterial Isolates. International Journal of Current Miccrobiology and Applied Science, 3(12), 962-970.

Bheemaraddi, M., Shivannavar, C., \& Gaddad, S. (2014). Effect of carbon and nitrogen sources on biodegradation of textile azo dye Reactive Violet 5 by Pseudomonas aeruginosa GSM3. Scholars Academic Journal of Biosciences (SAJB), 2(4), 285-289.

Chakraborty, S., Basak, B., Dutta, S., Bhunia, B., \& Dey, A. (2013) Decolorization and biodegradation of Congo red dye by a novel white rot fungus Alternaria alternata CMERI F6. Bioresource Technology, 147, 662-666. https://doi.org/10.1016/j.biortech.2013.08.117

Chaudhari, A. U., Tapase, S. R., Markad, V. L., \& Kodam, K. M. (2013). Simultaneous decolorization of reactive Orange M2R dye and reduction of chromate by Lysinibacillus sp. KMK-A. Journal of Hazardous Materials, 262, 580-588. https://doi.org/10.1016/j.jhazmat.2013.09.006

Chung, K.-T. (2016). Azo dyes and human health: A review. Journal of Environmental Science and Health, Part C, 34(4), 233-261. https://doi.org/10.1080/10590501.2016.1236602

Corso, C. R., \& Maganha de Almeida, A. C. (2009). Bioremediation of Dyes in Textile Effluents by Aspergillus oryzae. Microbial Ecology, 57(2), 384-390. https://doi.org/10.1007/s00248-008-9459-7
Das, A., \& Mishra, S. (2017). Removal of textile dye reactive green-19 using bacterial consortium: Process optimization using response surface methodology and kinetics study. Journal of Environmental Chemical Engineering, 5(1), 612627. https://doi.org/10.1016/j.jece.2016.10.005

Das, P., Banerjee, P., Zaman, A., \& Bhattacharya, P. (2016). Biodegradation of two Azo dyes using Dietzia sp. PD1: process optimization using Response Surface Methodology and Artificial Neural Network. Desalination and Water Treatment, 57(16), 7293-7301. https://doi.org/10.1080/19443994.2015.1013993 Deng, D., Guo, J., Zeng, G., \& Sun, G. (2008). Decolorization of anthraquinone, triphenylmethane and azo dyes by a new isolated Bacillus cereus strain DC11. International Biodeterioration \& Biodegradation, 62(3), 263-269. https://doi.org/10.1016/j.ibiod.2008.01.017

Dhanve, R. S., Shedbalkar, U. U., \& Jadhav, J. P. (2008). Biodegradation of diazo reactive dye Navy blue HE2R (Reactive blue 172) by an isolated Exiguobacterium sp. RD3. Biotechnology and Bioprocess Engineering, 13(1), 53-60. https://doi.org/10.1007/s12257-007-0165-y

dos Santos, A. B., Cervantes, F. J., \& van Lier, J. B. (2007). Review paper on current technologies for decolourisation of textile wastewaters: Perspectives for anaerobic biotechnology. Bioresource Technology, 98(12), 2369-2385. https://doi.org/10.1016/j.biortech.2006.11.013

Du, L.-N., Li, G., Zhao, Y.-H., Xu, H.-K., Wang, Y., Zhou, Y., \& Wang, L. (2015). Efficient metabolism of the azo dye methyl orange by Aeromonas sp. strain DH-6: Characteristics and partial mechanism. International $\begin{array}{llll}\text { Biodeterioration } \quad \& \quad \text { Biodegradation, } & 105, \text { 66-72 }\end{array}$ https://doi.org/10.1016/j.ibiod.2015.08.019

Dwivedi, K., \& Kumar, G. (2015). Genetic Damage Induced by a Food Coloring Dye (Sunset Yellow) on Meristematic Cells of Brassica campestris L. Journal of Environmental and Public Health, 2015, 1-5. https://doi.org/10.1155/2015/319727

Ebency, C. I. L., Rajan, S., Murugesan, A. G., Rajesh, R., \& Elayarajah, B. (2013). Biodegradation of textile azo dyes and its bioremediation potential using seed germination efficiency. International Journal of Current Microbiology and Applied Sciences, 2(10), 496-505.

Franciscon, E., Grossman, M., Paschoal, J. A., Reyes, F. G., \& Durrant, L. (2012). Decolorization and biodegradation of reactive sulfonated azo dyes by a newly isolated Brevibacterium sp. strain VN-15. SpringerPlus, 1(1), 37. https://doi.org/10.1186/2193-1801-1-37

Gao, Y., Li, C., Shen, J., Yin, H., An, X., \& Jin, H. (2011). Effect of Food Azo Dye Tartrazine on Learning and Memory Functions in Mice and Rats, and the Possible Mechanisms Involved. Journal of Food Science, 76(6), T125-T129. https://doi.org/10.1111/j.1750-3841.2011.02267.x

Garg, S. K., \& Tripathi, M. (2017). Microbial Strategies for Discoloration and Detoxification of Azo Dyes from Textile Effluents. Research Journal of Microbiology, 12(1), 1-19. https://doi.org/10.3923/jm.2017.1.19

Ghaedi, M., Ghaedi, A. M., Negintaji, E., Ansari, A., \& Mohammadi, F. (2014). Artificial neural network - Imperialist competitive algorithm based optimization for removal of sunset yellow using $\mathrm{Zn}(\mathrm{OH}) 2$ nanoparticles-activated carbon Journal of Industrial and Engineering Chemistry, 20(6), 4332-4343. https://doi.org/10.1016/j.jiec.2014.01.041

Gil, C. (2014). Toxicological effects of food additives - Azo dyes. SLU, Dept of Biomedical Sciences and Veterinary Public Health, 1-22.

Gomaa, E. Z. (2016). Biodegradation and Detoxification of Azo Dyes by Some Bacterial Strains. Microbiology Journal, 6(1), 15-24. https://doi.org/10.3923/mj.2016.15.24

Hafshejani, M. K., Ogugbue, C. J., \& Morad, N. (2014). Application of response surface methodology for optimization of decolorization and mineralization of triazo dye Direct Blue 71 by Pseudomonas aeruginosa. 3 Biotech, 4(6), 605-619. https://doi.org/10.1007/s13205-013-0192-7

Harazono, K., Watanabe, Y., \& Nakamura, K. (2003). Decolorization of Azo Dye by the White-Rot Basidiomycete Phanerochaete sordida and by Its Manganese Peroxidase. Journal of Bioscience and Bioengineering, 95(5), 455-459. https://doi.org/10.1263/jbb.95.455

Hassan, S. E., Fouda, A., Azab, M. S., \& Saied, E. (2015). International Journal of Environmental Biology Original Article Biological decolorization of different azo dyes using two bacterial strains of Klebsiella spp . and their consortium. International Journal of Environmental Biology, 5(4), 104-114.

He, F., Qin, X., Zhang, H., Yang, Y., Zhang, X., \& Yang, Y. (2015) Characterization of laccase isoenzymes from the white-rot fungus Ganoderma sp.En3 and synergistic action of isoenzymes for dye decolorization. Journal of Chemical Technology \& Biotechnology, 90(12), 2265-2279. https://doi.org/10.1002/jctb.4543

Hema, N., \& Suresha, S. (2015). Optimization of Fungal Decolorization of Isolan Grey using Plackett-Burman Experimental Design. Research in Chemistry and Environment, 5(2), 26-34.

Huang, G., Wang, W., \& Liu, G. (2015). Simultaneous chromate reduction and azo dye decolourization by Lactobacillus paracase CL1107 isolated from deep sea sediment. Journal of Environmental Management, 157, 297-302. https://doi.org/10.1016/j.jenvman.2015.04.031 
Illakkiam, D., Subha, D., Ahila, V., \& Geetha, N. (2016). Decolorization of alizarin red $\mathrm{s}$ dye by bacterial strains isolated from industrial effluents. International Journal of Plant, Animal and Environmental Sciences, 1, 268-276. Jadhav, J. P., Kalyani, D. C., Telke, A. A., Phugare, S. S., \& Govindwar, S. P. (2010). Evaluation of the efficacy of a bacterial consortium for the removal of color, reduction of heavy metals, and toxicity from textile dye effluent. Bioresource Technology, 101(1), 165-173 https://doi.org/10.1016/j.biortech.2009.08.027

Jadhav, S. B., Surwase, S. N., Phugare, S. S., \& Jadhav, J. P. (2013). Response surface methodology mediated optimization of Remazol Orange decolorization in plain distilled water by Pseudomonas aeruginosa $\mathrm{BCH}$. International Journal of Environmental Science and Technology, 10(1), 181-190. https://doi.org/10.1007/s13762-012-0088-9

Jadhav, U. U., Dawkar, V. V., Tamboli, D. P., \& Govindwar, S. P. (2009) Purification and characterization of veratryl alcohol oxidase from Comamonas sp. UVS and its role in decolorization of textile dyes. Biotechnology and Bioprocess Engineering, 14(3), 369-376. https://doi.org/10.1007/s 12257-008 0300-4

Jaiswal, S. S., \& Gomashe, A. V. (2017). Bioremediation of textile azo dyes by newly isolated Bacillus sp. from dye contaminated soil. International Journal of Biotechnology and Biochemistry, 13(2), 147-153.

Jiang, M., Ten, Z., \& Ding, S. (2013). Decolorization of Synthetic Dyes by Crude and Purified Laccases from Coprinus comatus Grown Under Different Cultures: The Role of Major Isoenzyme in Dyes Decolorization. Applied Biochemistry and Biotechnology, 169(2), 660-672. https://doi.org/10.1007/s12010-012-0031-z

Johari, W. L. W. (2014). Biodecolorization of Azo Dyes by Microorganisms Isolated From Serdang and Merambong Soils. Bioremediation Science and Technology Research, 2(1 SE-Articles).

Karatay, S. E., Kılıç, N. K., \& Dönmez, G. (2015). Removal of Remazol Blue by azoreductase from newly isolated bacteria. Ecological Engineering, 84, 301-304. https://doi.org/10.1016/j.ecoleng.2015.09.037

Kaur, B., Kumar, B., Garg, N., \& Kaur, N. (2015). Statistical Optimization of Conditions for Decolorization of Synthetic Dyes by Cordyceps militaris MTCC 3936 Using RSM. BioMed Research International, 2015, 1-17. https://doi.org/10.1155/2015/536745

Khalid, A., Arshad, M., \& Crowley, D. E. (2008). Accelerated decolorization of structurally different azo dyes by newly isolated bacterial strains. Applied Microbiology and Biotechnology, 78(2), 361-369. https://doi.org/10.1007/s00253-007-1302-4

Khan, Z., Jain, K., Soni, A., \& Madamwar, D. (2014). Microaerophilic degradation of sulphonated azo dye - Reactive Red 195 by bacterial consortium AR1 through co-metabolism. International Biodeterioration \& Biodegradation, 94, 167-175. https://doi.org/10.1016/j.ibiod.2014.07.002

Khataee, A. R., Dehghan, G., Ebadi, A., Zarei, M., \& Pourhassan, M. (2010) Biological treatment of a dye solution by Macroalgae Chara sp.: Effect of operational parameters, intermediates identification and artificial neural network modeling. Bioresource Technology, 101(7), 2252-2258 https://doi.org/10.1016/j.biortech.2009.11.079

Krishnan, J., Arvind Kishore, A., Suresh, A., Madhumeetha, B., \& Gnana Prakash, D. (2017). Effect of $\mathrm{pH}$, inoculum dose and initial dye concentration on the removal of azo dye mixture under aerobic conditions. International Biodeterioration \& Biodegradation, $119, \quad 16-27$. https://doi.org/10.1016/j.ibiod.2016.11.024

Kuddus, M., Joseph, B., \& Wasudev Ramteke, P. (2013). Production of laccase from newly isolated Pseudomonas putida and its application in bioremediation of synthetic dyes and industrial effluents. Biocatalysis and Agricultural Biotechnology, 2(4), 333-338. https://doi.org/10.1016/j.bcab.2013.06.002

Kumar Garg, S., Tripathi, M., Singh, S. K., \& Tiwari, J. K. (2012). Biodecolorization of textile dye effluent by Pseudomonas putida SKG-1 (MTCC 10510) under the conditions optimized for monoazo dye orange II color remova in simulated minimal salt medium. International Biodeterioration \& Biodegradation, 74, 24-35. https://doi.org/10.1016/j.ibiod.2012.07.007

Kurade, M. B., Waghmode, T. R., Khandare, R. V., Jeon, B.-H., \& Govindwar, S. P. (2016). Biodegradation and detoxification of textile dye Disperse Red 54 by Brevibacillus laterosporus and determination of its metabolic fate. Journal of $\begin{array}{llll}\text { Bioscience and } & \text { Bioengineering, } & \text { 121(4), }\end{array}$ https://doi.org/10.1016/j.jbiosc.2015.08.014

Kurade, M. B., Waghmode, T. R., Tamboli, D. P., \& Govindwar, S. P. (2013) Differential catalytic action of Brevibacillus laterosporus on two dissimilar azo dyes Remazol red and Rubine GFL. Journal of Basic Microbiology, 53(2), 136146. https://doi.org/10.1002/jobm.201100402

Lade, H., Kadam, A., Paul, D., \& Govindwar, S. (2015). Biodegradation and detoxification of textile azo dyes by bacterial consortium under sequential microaerophilic/aerobic processes. EXCLI Journal 201, 14, 158-174.

Lade, H. S., Waghmode, T. R., Kadam, A. A., \& Govindwar, S. P. (2012). Enhanced biodegradation and detoxification of disperse azo dye Rubine GFL and textile industry effluent by defined fungal-bacterial consortium. International $\begin{array}{llll}\text { Biodeterioration } \quad \& \quad \text { Biodegradation, } & 72,107 .\end{array}$ https://doi.org/10.1016/j.ibiod.2012.06.001
Lalnunhlimi, S., \& Krishnaswamy, V. (2016). Decolorization of azo dyes (Direct Blue 151 and Direct Red 31) by moderately alkaliphilic bacterial consortium. Brazilian Journal of Microbiology, 47(1), 39-46. https://doi.org/10.1016/j.bjm.2015.11.013

Lavanya, C., Dhankar, R., Chhikara, S., \& Sheoran, S. (2014). Review Article Degradation of Toxic Dyes: A Review. International Journal of Current Microbiology and Applied Sciences, 3(6), 189-199.

Li, H.-X., Xu, B., Tang, L., Zhang, J.-H., \& Mao, Z.-G. (2015). Reductive decolorization of indigo carmine dye with Bacillus sp. MZS10. International Biodeterioration \& Biodegradation, $\quad 103, \quad 30-37$. https://doi.org/10.1016/j.ibiod.2015.04.007

Liu, W., Liu, C., Liu, L., You, Y., Jiang, J., Zhou, Z., \& Dong, Z. (2017). Simultaneous decolorization of sulfonated azo dyes and reduction of hexavalent chromium under high salt condition by a newly isolated salt-tolerant strain Bacillus circulans BWL1061. Ecotoxicology and Environmental Safety, 141(March), 9-16. https://doi.org/10.1016/j.ecoenv.2017.03.005

Lone, T. A., Revathi, C., \& Lone, R. A. (2015). Isolation of Dye Degrading Bacillus Species from the Soil near Dyeing Industry and Its Potential Application in Dye Effluent Treatment. American-Eurasian Journal of Toxicological Sciences, 7(3), 129-135. https://doi.org/10.5829/idosi.aejts.2015.7.3.94162

Mahmood, S., Khalid, A., Arshad, M., Mahmood, T., \& Crowley, D. E. (2015) Detoxification of azo dyes by bacterial oxidoreductase enzymes. Critical Reviews in Biotechnology, 36(4), 1-13. https://doi.org/10.3109/07388551.2015.1004518 Maqbool, Z., Hussain, S., Ahmad, T., Nadeem, H., Imran, M., Khalid, A., Abid, M., \& Martin-Laurent, F. (2016). Use of RSM modeling for optimizing decolorization of simulated textile wastewater by Pseudomonas aeruginosa strain ZM130 capable of simultaneous removal of reactive dyes and hexavalent chromium. Environmental Science and Pollution Research, 23(11), 11224 11239. https://doi.org/10.1007/s11356-016-6275-3

Min, K., Gong, G., Woo, H. M., Kim, Y., \& Um, Y. (2015). A dye-decolorizing peroxidase from Bacillus subtilis exhibiting substrate-dependent optimum temperature for dyes and $\beta$-ether lignin dimer. Scientific Reports, 5(1), 8245 https://doi.org/10.1038/srep08245

Mohan, S. V., Bhaskar, Y. V., \& Karthikeyan, J. (2004). Biological decolourisation of simulated azo dye in aqueous phase by algae Spirogyra species. International Journal of Environment and Pollution, 21(3), 211 https://doi.org/10.1504/IJEP.2004.004190

Mohana, S., Shrivastava, S., Divecha, J., \& Madamwar, D. (2008). Response surface methodology for optimization of medium for decolorization of textile dye Direct Black 22 by a novel bacterial consortium. Bioresource Technology, 99(3), 562-569. https://doi.org/10.1016/j.biortech.2006.12.033

N. Arunagirinathan, S. A. K., J. Hemapriya, S. V., \& Indra, V. (2017) Bioremediation and Detoxification of a Textile Azo Dye-Evans Blue by Bacterial Strain AKIP-2. International Journal of Current Microbiology and Applied Sciences, 6(4), 2687-2694. https://doi.org/10.20546/ijcmas.2017.604.313

Neifar, M., Jaouani, A., Kamoun, A., Ellouze-Ghorbel, R., \& Ellouze-Chaabouni, S. (2011). Decolorization of Solophenyl Red 3BL Polyazo Dye by LaccaseMediator System: Optimization through Response Surface Methodology Enzyme Research, 2011(1), 1-8. https://doi.org/10.4061/2011/179050

Ogugbue, C. J., \& Sawidis, T. (2011). Optimisation of process parameters for bioreduction of azo dyes using Bacillus firmus under batch anaerobic condition. International Journal of Environmental Studies, 68(5), 651-665. https://doi.org/10.1080/00207233.2011.578353

Pandey, A., Singh, P., \& Iyengar, L. (2007). Bacterial decolorization and degradation of azo dyes. International Biodeterioration \& Biodegradation, 59(2), 73-84. https://doi.org/10.1016/j.ibiod.2006.08.006

Phugare, S. S., Waghmare, S. R., \& Jadhav, J. P. (2011). Purification and characterization of dye degrading of veratryl alcohol oxidase from Pseudomonas aeruginosa strain BCH. World Journal of Microbiology and Biotechnology, 27(10), 2415-2423. https://doi.org/10.1007/s11274-011-0714-6

Ponraj, M., Gokila, K., \& Zambare, V. (2011). Bacterial Decolorization of Textile Dye- Orange 3R. International Journal of Advanced Biotechnology and Research, 2(1), 168-177.

Puvaneswari, N., Muthukrishnan, J., \& Gunasekaran, P. (2006). Toxicity assessment and microbial degradation of azo dyes. Indian Journal of Experimental Biology, 44(8), 618-626.

Rajan, S., Murugesan, A. G., Rajesh, R., \& Elayarajah, B. (2013). Original Research Article Biodegradation of textile azo dyes and its bioremediation potential using seed germination efficiency. International Journal of Current Microbiology and Applied Sciences, 2(10), 496-505.

Ribeiro, A. R., \& Umbuzeiro, G. de A. (2014). Effects of a textile azo dye on mortality, regeneration, and reproductive performance of the planarian, Girardia tigrina. Environmental Sciences Europe, 26(1), 22 https://doi.org/10.1186/s12302-014-0022-5

Sahasrabudhe, M. M., Saratale, R. G., Saratale, G. D., \& Pathade, G. R. (2014). Decolorization and detoxification of sulfonated toxic diazo dye C.I. Direct Red 81 by Enterococcus faecalis YZ 66. Journal of Environmental Health Science and Engineering, 12(1), 151. https://doi.org/10.1186/s40201-014-0151-1

Santos, A., Mendes, S., Brissos, V., \& Martins, L. O. (2014). New dye decolorizing peroxidases from Bacillus subtilis and Pseudomonas putida MET94 
towards biotechnological applications. Applied Microbiology and Biotechnology, 98(5), 2053-2065. https://doi.org/10.1007/s00253-013-5041-4

Saratale, R. G., Saratale, G. D., Chang, J. S., \& Govindwar, S. P. (2011) Bacterial decolorization and degradation of azo dyes: A review. Journal of the Taiwan Institute of Chemical Engineers, 42(1), 138-157. https://doi.org/10.1016/j.jtice.2010.06.006

Sathian, S., Radha, G., Shanmugapriya, V., Rajasimman, M., \& Karthikeyan, C. (2013). Optimization and kinetic studies on treatment of textile dye wastewater using Pleurotus floridanus. Applied Water Science, 3(1), 41-48 https://doi.org/10.1007/s13201-012-0055-0

Senthilkumar, S., Perumalsamy, M., Prabhuy, H., AhmedBasha, C., \& Anantharaman, N. (2012). Response surface optimization for efficient dye removal by isolated strain Pseudomonas sp. Open Engineering, 2(3), 425-434 https://doi.org/10.2478/s13531-012-0001-9

Senthilkumar, S., Prabhu, H. J., \& Perumalsamy, M. (2013). Response surface Optimization for Biodegradation of Textile Azo dyes using isolated bacterial strain Pseudomonas sp. Arabian Journal for Science and Engineering, 38(9), 2279-2291. https://doi.org/10.1007/s13369-012-0507-8

Shah, M., Patel, K., \& Nair, S. (2013). Microbiological removal of crystal violet dye by Bacillus subtilis ETL-2211. OA Biotechnology, 2(2), 1-7. https://doi.org/10.13172/2052-0069-2-2-548

Sharma, P., Singh, L., \& Dilbaghi, N. (2009). Optimization of process variables for decolorization of Disperse Yellow 211 by Bacillus subtilis using BoxBehnken design. Journal of Hazardous Materials, 164(2-3), 1024-1029. https://doi.org/10.1016/j.jhazmat.2008.08.104

Singh, R. L., Singh, P. K., \& Singh, R. P. (2015). Enzymatic decolorization and degradation of azo dyes - A review. International Biodeterioration \& Biodegradation, 104, 21-31. https://doi.org/10.1016/j.ibiod.2015.04.027

Singh, R., Singh, R., \& Singh, P. (2014). Bacterial decolorization of textile azo dye acid orange by Staphylococcus hominis RMLRT03. Toxicology International, 21(2), 160. https://doi.org/10.4103/0971-6580.139797

Solís, M., Solís, A., Pérez, H. I., Manjarrez, N., \& Flores, M. (2012). Microbial decolouration of azo dyes: A review. Process Biochemistry, 47(12), 1723-1748. https://doi.org/10.1016/j.procbio.2012.08.014

Song, L., Shao, Y., Ning, S., \& Tan, L. (2017). Performance of a newly isolated salt-tolerant yeast strain Pichia occidentalis G1 for degrading and detoxifying azo dyes. Bioresource Technology, 233, 21-29. https://doi.org/10.1016/j.biortech.2017.02.065

Srinivasan, V., Saravana Bhavan, P., \& Krishnakumar, J. (2014). Bioremediation of Textile Dye Effluent By Bacillus and Pseudomonas spp. International Journal of Science, Environment and Technology, 3(6), 2215-2224.

Sudha, M., \& Saranya, a. (2014). Microbial degradation of Azo Dyes: A review. Int. J. Curr. Microbiol. ..., 3(2), 670-690.

Tahir, U., Yasmin, A., \& Khan, U. H. (2016). Phytoremediation: Potential flora for synthetic dyestuff metabolism. Journal of King Saud University - Science, 28(2), 119-130. https://doi.org/10.1016/j.jksus.2015.05.009

Tan, L., He, M., Song, L., Fu, X., \& Shi, S. (2016). Aerobic decolorization, degradation and detoxification of azo dyes by a newly isolated salt-tolerant yeas Scheffersomyces spartinae TLHS-SF1. Bioresource Technology, 203, 287-294. https://doi.org/10.1016/i.biortech.2015.12.058

Telke, A. A., Joshi, S. M., Jadhav, S. U., Tamboli, D. P., \& Govindwar, S. P. (2010). Decolorization and detoxification of Congo red and textile industry effluent by an isolated bacterium Pseudomonas sp. SU-EBT. Biodegradation, 21(2), 283-296. https://doi.org/10.1007/s10532-009-9300-0

Verma, A. K., Dash, R. R., \& Bhunia, P. (2012). A review on chemical coagulation/flocculation technologies for removal of colour from textile wastewaters. Journal of Environmental Management, 93(1), 154-168. https://doi.org/10.1016/j.jenvman.2011.09.012

Waghmode, T. R., Kurade, M. B., Lade, H. S., \& Govindwar, S. P. (2012) Decolorization and Biodegradation of Rubine GFL by Microbial Consortium GG-BL in Sequential Aerobic/Microaerophilic Process. Applied Biochemistry and Biotechnology, 167(6), 1578-1594. https://doi.org/10.1007/s12010-0129585-Z

Witek-Krowiak, A., Chojnacka, K., Podstawczyk, D., Dawiec, A., \& Pokomeda K. (2014). Application of response surface methodology and artificial neural network methods in modelling and optimization of biosorption process. Bioresource Technology, 160, 150-160. https://doi.org/10.1016/j.biortech.2014.01.021

Yagub, M. T., Sen, T. K., Afroze, S., \& Ang, H. M. (2014). Dye and its removal from aqueous solution by adsorption: A review. Advances in Colloid and Interface Science, 209, 172-184. https://doi.org/10.1016/j.cis.2014.04.002

Yan, J., Chen, D., Yang, E., Niu, J., Chen, Y., \& Chagan, I. (2014). Purification and characterization of a thermotolerant laccase isoform in Trametes trogii strain and its potential in dye decolorization. International Biodeterioration \& Biodegradation, 93, 186-194. https://doi.org/10.1016/j.ibiod.2014.06.001

Yang, Y., Wang, G., Wang, B., Li, Z., Jia, X., Zhou, Q., \& Zhao, Y. (2011). Biosorption of Acid Black 172 and Congo red from aqueous solution by nonviable Penicillium YW 01: Kinetic study, equilibrium isotherm and artificial neural network modeling. Bioresource Technology, 102(2), 828-834 https://doi.org/10.1016/j.biortech.2010.08.125
Zhuo, R., Yuan, P., Yang, Y., Zhang, S., Ma, F., \& Zhang, X. (2017). Induction of laccase by metal ions and aromatic compounds in Pleurotus ostreatus HAUCC 162 and decolorization of different synthetic dyes by the extracellular laccase. $\begin{array}{llll}\text { Biochemical Engineering } & \text { Journal, } & \text { 117, }\end{array}$ https://doi.org/10.1016/j.bej.2016.09.016

Zucca, P., Cocco, G., Sollai, F., \& Sanjust, E. (2016). Fungal laccases as tools for biodegradation of industrial dyes. Biocatalysis, 1(1), 82-108. https://doi.org/10.1515/boca-2015-0007 